\title{
Protection of rescuers in emergency care: where does Hong Kong stand?
}

\author{
Abraham KC Wai *, MB, ChB, FHKAM (Emergency Medicine) \\ Emergency Medicine Unit, Li Ka Shing Faculty of Medicine, The University of Hong Kong, Pokfulam, Hong Kong \\ *Corresponding author: awai@hku.hk
}

\begin{abstract}
Hong Kong Med J 2017;23:656-7
\end{abstract}
DOI: 10.12809/hkmj177032

It is known that in cardiac arrest the chance of survival drops with time. Bystander cardiopulmonary resuscitation (CPR) should be initiated as soon as possible, preferably when the patient collapses. ${ }^{1}$ Fan et $\mathrm{al}^{2}$ recently reported 5154 cases of out-of-hospital cardiac arrest (OHCA) among which bystander CPR and automated external defibrillator (AED) use were performed in $28.8 \%$ and $1.4 \%$ of cases, respectively. Another Hong Kong study at a teaching hospital in 2005 showed that bystander CPR was offered in 15\% of OHCA patients. ${ }^{3}$

Fear of legal liability contributes to the reluctance of trained bystanders to help. ${ }^{4-6}$ Good Samaritan law, which is based on biblical teaching of the virtue of helping someone in need, ${ }^{7}$ is available in a number of jurisdictions globally, including China, but not Hong Kong.

In most common law jurisdictions, if a person initiates a rescue, he/she may assume an obligation to carry it out with reasonable competence. The rescuer will only be liable to the extent that his/her own act caused additional damage. The position of doctors in rescues is unclear. They must adhere to the Code of Conduct and may be in breach of this if they fail to act. The International Code of Medical Ethics has been incorporated into the Code of Professional Conduct of the Medical Council of Hong Kong (MCHK) and provides that:

A PHYSICIAN SHALL give emergency care as a humanitarian duty unless he/she is assured that others are willing and able to give such care. $^{8}$

While the MCHK, in the process of a disciplinary hearing, refers to the International Code to adjudicate, it is not known if MCHK would penalise a doctor if he/she actively denied being a doctor, failed to offer himself/herself as a doctor, or refused to assist in an emergency situation.

A Good Samaritan law would not protect those who were guilty of gross negligence, but would protect those who had responded in good faith and made a good-faith error in judgement. A doctor does what he/she has been taught to do in a Basic Life Support course. He/she will not be deemed to have been grossly negligent if an attempt to give care to a person in distress fails.
Shenzhen Special Economic Zone Good Samaritans' Rights Protection Regulation (深圳經濟 特區救助人權益保護規定), the first Good Samaritan law in China, was promulgated and became effective in 2013. ${ }^{9}$ Shanghai and Beijing followed in 2016 and 2017, respectively. ${ }^{10,11}$ Good Samaritans will be protected from liability under China's new General Provisions of the Civil Law that was passed in March 2017. ${ }^{12}$

In the United Kingdom, the Social Action, Responsibility and Heroism Act 2015 (the SARAH Act) came into force in 2015. Section 4 covers the Good Samaritan principle. ${ }^{13}$ Nonetheless, compared with the common law counterpart, the SARAH Act does not provide qualified immunity with a set of legal tests, or amend the common law. The Good Samaritan act was passed into law in 2011 in Ireland. ${ }^{14}$ Specifically, that law refers to the provision of assistance, advice, or care to a person for the administration of first-aid treatment using an AED, and the transportation of the victim/patient from the scene of an emergency to medical care.

Hong Kong continues to follow the common law tradition despite the transfer of sovereignty. The number of complaints received by the Hospital Authority about medical services reached a record high in 2015/16. ${ }^{15}$ Although no legal action has been initiated against a rescuer in Hong Kong, instances wherein a health care professional acts as a Good Samaritan are not rare. The legal risk associated with resuscitation should not be underestimated.

To enhance the survival of patients with cardiac arrest, a primary measure could involve populationbased education about CPR and AED, to enhance recognition by the general public of cardiac arrest and their confidence and ability to offer assistance. We must avoid the scenario where a patient's survival is compromised because a trained bystander is reluctant to help for fear of legal retribution. The protection of liability in Good Samaritan law should encourage bystanders to assist, without fear of being sued or prosecuted for unintentional injury or wrongful death.

\section{References}

1. Eisenberg MS, Bergner L, Hallstrom A. Cardiac 
resuscitation in the community. Importance of rapid provision and implications for program planning. JAMA 1979;241:1905-7.

2. Fan KL, Leung LP, Siu YC. Out-of-hospital cardiac arrest in Hong Kong: a territory-wide study. Hong Kong Med J 2017;23:48-53.

3. Wai AK, Cameron P, CK Cheung, Mak P, Rainer TH. Outof-hospital cardiac arrest in a teaching hospital in Hong Kong: descriptive study using the Utstein style. Hong Kong J Emerg Med 2005;12:148-55.

4. Abella BS, Aufderheide TP, Eigel B, et al. Reducing barriers for implementation of bystander-initiated cardiopulmonary resuscitation: a scientific statement from the American Heart Association for healthcare providers, policymakers, and community leaders regarding the effectiveness of cardiopulmonary resuscitation. Circulation 2008;117:704-9.

5. Sasson C, Haukoos JS, Bond C, et al. Barriers and facilitators to learning and performing cardiopulmonary resuscitation in neighborhoods with low bystander cardiopulmonary resuscitation prevalence and high rates of cardiac arrest in Columbus, OH. Circ Cardiovasc Qual Outcomes 2013;6:550-8.

6. Fernandez R; St John Ambulance. Social action, responsibility and Heroism bill: St John Ambulance submission to the Public Bill Committee. Available from: https://www.sja.org.uk/sja/pdf/SARAH-SJA-submission. pdf. Accessed 14 May 2017.

7. The Holy Bible. Luke 10:31-36.
8. Medical Council of Hong Kong. Code of Professional Conduct: for the Guidance of Registered Medical Practitioners. Revised in January 2-16. Available from: http://www.mchk.org.hk/english/code/files/Code_of_ Professional_Conduct_2016.pdf. Accessed 15 May 2017.

9. 《深圳经济特区救助人权益保护规定》. Available from: http://gongwen.cnrencai.com/guiding/65093.html. Accessed 16 May 2017.

10. 《上海市急救醫療服務條例》. Available from: http:// www.spcsc.sh.cn/n1939/n2440/n3273/u1ai133774.html. Accessed 2 Sep 2017.

11. Regulation of the Beijing Municipality on the Pre-hospital Emergency Medical Service. 《北京市院前醫療急救服務 條例》. Available from: http://www.lawinfochina.com/ display.aspx lib=law\&id=22525\&EncodingName=big5. Accessed 2 Sep 2017.

12. Article 184, General Principles of the Civil Law of the People's Republic of China. http://www.chinacourt.org/ law/detail/2017/03/id/149272.shtml. Accessed 24 May 2017.

13. Howard County Library Note: SARAH Bill, SN/HA/6997. 28 January 2015.

14. Part IVA of the Civil Law (Miscellaneous Provisions) Act 2011, Laws of the Republic of Ireland.

15. Hospital Authority: Annual report on public appreciation, feedback \& complaints management. Available from: http://www.ha.org.hk/haho/ho/pred/AnnualReport.pdf. Accessed 24 May 2017. 